\title{
Evaluation of a real-time PCR assay for diagnosis of schistosomiasis japonica in the domestic goat
}

\author{
Qinghong Guo ${ }^{1}$, Cheng Chen' ', Keke Zhou', Yugang Li', Laibao Tong ${ }^{3}$, Yongcheng Yue', Kerou Zhou',
} Jinming Liu', Zhiqiang Fu' ${ }^{1}$, Jiaojiao Lin' ${ }^{1}$, Jiaxi Zhao ${ }^{3}$, Pengxiang Sun ${ }^{4}$ and Yang Hong ${ }^{1 *}$

\begin{abstract}
Background: Schistosomiasis japonica is an infectious disease caused by Schistosoma japonicum that seriously endangers human health. Domestic animals have important roles in disease transmission and goats are considered a primary reservoir host and source of infection. The prevalence and intensity of schistosomiasis infections have signifcantly decreased in China, and a more sensitive, specific detection method is urgently needed. The aim of this study was to develop a real-time PCR assay for accurate detection of S. japonicum infection in goats.
\end{abstract}

Methods: A real-time PCR method for detecting schistosomiasis japonica in goats was developed by amplification of a specific S. japonicum DNA fragment, and validated using a total of 94 negative and 159 positive plasma and serum samples collected in our previous study of S. japonicum infection. Both plasma and serum samples were evaluated by real-time PCR and enzyme-linked immunosorbent assay (ELISA). In addition, 120 goat plasma samples from an S. japonicum-endemic area (Wangjiang) and 33 from a non-endemic region (Weihai) were collected and evaluated using our method.

Results: The sensitivity and specificity of the real-time PCR for detecting infected samples were $98.74 \%(157 / 159$, 95\% Cl: 95.53-99.85\%) and 100\% (94/94, 95\% Cl: 96.15-100\%), respectively. For the ELISA, sensitivity and specificity were $98.11 \%$ (156/159, 95\% Cl: 94.59-99.61\%) and 90.43\% (85/94, 95\% Cl: 82.60-95.53\%), respectively. Further, we found positivity rates for S. japonicum infection in Wangjiang and Weihai of 8.33\% (10/120, 95\% Cl: 4.07-14.79\%) and 0\% (0/33, 95\% Cl: 0-10.58\%), respectively.

Conclusions: The results of this study indicate that our real-time PCR method exhibits higher sensitivity and specificity than ELISA and is a useful method for detection of S. japonicum infection in goats.

Keywords: Schistosoma japonicum, Diagnosis, Real-time PCR, ELISA, Goats

\section{Background}

Schistosomiasis is a significant infectious disease caused by trematode worms of the genus Schistosoma, which is a global public health concern. Worldwide, schistosomiasis

\footnotetext{
*Correspondence: hongyang_7@126.com

${ }^{1}$ National Reference Laboratory of Animal Schistosomiasis, Key Laboratory of Animal Parasitology of Ministry of Agriculture, Shanghai Veterinary Research Institute, Chinese Academy of Agricultural Sciences, Shanghai 200241, P. R. China

Full list of author information is available at the end of the article
}

is the second most devastating parasitic disease after malaria, and it is mainly distributed in Asia, South America and Africa $[1,2]$. The three major schistosome species that cause infection in humans are Schistosoma japonicum, Schistosoma mansoni and Schistosoma haematobium, among which, S. japonicum is mainly distributed in southeast Asian (China, The Philippines, etc.). According to previous studies, more than a million humans are infected with $S$. japonicum. Therefore, the disease remains a potential public health issue, despite

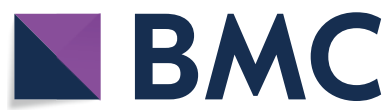

(c) The Author(s) 2020. This article is licensed under a Creative Commons Attribution 4.0 International License, which permits use, sharing, adaptation, distribution and reproduction in any medium or format, as long as you give appropriate credit to the original author(s) and the source, provide a link to the Creative Commons licence, and indicate if changes were made. The images or other third party material in this article are included in the article's Creative Commons licence, unless indicated otherwise in a credit line to the material. If material is not included in the article's Creative Commons licence and your intended use is not permitted by statutory regulation or exceeds the permitted use, you will need to obtain permission directly from the copyright holder. To view a copy of this licence, visit http://creativecommons.org/licenses/by/4.0/. The Creative Commons Public Domain Dedication waiver (http//creativecommons.org/publicdomain/zero/1.0/) applies to the data made available in this article, unless otherwise stated in a credit line to the data. 
considerable success in blocking transmission over the past decades [3-5].

Eradicating sources of infection is a vital strategy to eliminate schistosomiasis japonica [6]. Domestic animals are the primary source of infection and play an important role in disease transmission. In addition to bovines, goats are recognized as another major reservoir host in China [7]. Given the significantly decreasing prevalence and intensity of infection in China, development of a diagnostic method with high sensitivity and specificity for testing domestic animals is critical for effective control of schistosomiasis japonica [8].

Pathogenic and immunological diagnosis methods are used commonly for detection of S. japonicum infection. Pathogenic diagnosis primarily involves the Kato-Katz technique and miracidium hatching test (MHT), which have been regarded as the 'gold standard' for diagnosis of schistosomiasis $[9,10]$. These approaches are used widely because of their low cost and portability; however, their disadvantages include low sensitivity in areas with low-intensity infections and the fact that they are relatively time-consuming [11]. Immunological diagnostic methods include enzyme-linked immunosorbent assay (ELISA) and the indirect hemagglutination (IHA) test, in addition to other methods based on the antibody and antigen reaction [12, 13]. These approaches have higher sensitivity and are simple to apply; however, they have higher cross-reactivity and false positive rates [14]. Given the limitations of pathogenic and immunological diagnosis methods, a more sensitive and specific detection technique is required for schistosomiasis diagnosis [15].

With the development of molecular diagnostic technology, nucleic acid detection of S. japonicum infection has become a research hotspot in recent years. Many studies have demonstrated that nucleic acid detection of $S$. japonicum infection has higher sensitivity and specificity, and less cross-reactivity than traditional methods [7, 16-18]. Molecular diagnostic techniques used include general PCR, nested-PCR, real-time PCR, loop-mediated isothermal amplification (LAMP), and recombinant enzyme polymerase amplification (RPA), among others [19]. In many previous studies, highly repetitive schistosome gene sequences were used as targets for nucleic acid detection of schistosomiasis. These sequences were mainly cell-free circulating schistosome DNA, derived from the dead worms during migration and the epidermal tissue cells, during their growth process [20-22]. In this study, a real-time PCR method for detecting $S$. japonicum DNA in goat plasma was developed and used to evaluate $S$. japonicum infection in goats from endemic and non-endemic regions.

\section{Methods}

\section{Worm and egg collection}

Adult S. japonicum worms (42 days post-infection) were collected from the portal vein systems of five BALB/c mice artificially infected with S. japonicum cercariae [23]. Male and female $S$. japonicum worms were manually separated and S. japonicum eggs collected from infected BALB/c mouse livers [24]. All S. japonicum worms and eggs were stored in RNAlater (Sigma-Aldrich, St. Louise, USA) at $-20^{\circ} \mathrm{C}$ until use.

\section{Collection of plasma and serum samples}

A total of 159 positive plasma and serum samples were simultaneously collected from artificially infected goats. The goat was restrained by a special restraint device, which could make it supine lying, preventing the animal from struggling. The abdominal wool was shaved off and an area of skin of approximately $10 \times 10 \mathrm{~cm}$ was exposed. Then, goats were percutaneously infected with 300 cercariae for 20 min after counting the cercariae under a microscope. In addition, a total of 94 plasma and serum samples were collected from 94 goats without schistosome infection. Plasma and serum samples were collected respectively in EDTAK2 vacuum blood collection tubes and a vacuum blood collection tubes with no additive. The blood was collected from jugular vein of each goat, and the supernatant was separated after centrifugation at $3000 \times \mathrm{rpm}$ for $10 \mathrm{~min}$ at $25{ }^{\circ} \mathrm{C}$. Plasma samples from 120 goats which grazed freely on marshlands were collected in Wangjiang county, which is a region endemic for schistosomiasis japonica in Anhui Province, China. Further, plasma samples from 33 goats which grazed freely on farms were collected in Weihai city, which is a non-endemic area for schistosomiasis japonica in Shandong Province, China. All plasma and serum samples were stored at $-20^{\circ} \mathrm{C}$ until use. In addition, 32 positive plasma samples and their corresponding serum samples, as well as 10 positive plasma samples, were selected randomly for storage and use in later experiments.

\section{Plasma storage}

The 10 positive plasma samples were randomly selected, divided into 4 aliquots of $6 \mathrm{ml}$ each, and stored at $4{ }^{\circ} \mathrm{C}$, $-20{ }^{\circ} \mathrm{C},-40{ }^{\circ} \mathrm{C}$ and $-80{ }^{\circ} \mathrm{C}$, respectively. Samples were analyzed after 14 days, 28 days, 42 days, 3 months, 6 months, and 1 year of storage.

\section{Extraction of genomic and circulating DNA}

Genomic DNA was extracted from the tissues of an uninfected goat, and from male and female S. japonicum worms and eggs using a TIANamp Genomic DNA Kit (Tiangen Biotech, Beijng, China), according to the manufacturer's instructions. Genomic DNA samples from Haemonchus 
contortus, Fasciola gigantica, Toxoplasma gondii, Sarcocystis sp., Trichinella spiralis, Paramphistomum, Babesia, and Spirometra were provided by our institute and stored at $-20^{\circ} \mathrm{C}$.

DNA was extracted from goat plasma/serum samples using a Magnetic Serum/Plasma Circulating DNA Maxi Kit (Tiangen Biotech), according to the manufacturer's instructions. Extracted DNA samples were stored at $-20^{\circ} \mathrm{C}$.

\section{Establishment and optimization of the real-time PCR detection system}

PCR primers were designed according to a DNA fragment containing S. japonicum target sequence (GenBank: FN356222.1), which was verified through bioinformatics analysis and some screening experiments in our laboratory: forward primer 1 (FP1: 5'-GCA GCG GCT TTA GGC AAC AC-3') and reverse primer 1 (RP1: 5'-TCA AAC TAA TCC CTC TAT GGT TAT CAC AAG-3) (Fig. 1). PCR was performed using LA Taq DNA polymerase (Takara, Kyoto, Japan). The total reaction volume was $50 \mu \mathrm{l}$ and included 5 $\mu \mathrm{l} 10 \times$ LA PCR Buffer II ( $\mathrm{Mg}^{2+}$ plus), $8 \mu \mathrm{l}$ dNTP mixture, $0.5 \mu \mathrm{l} \mathrm{TaKaRa} \mathrm{LA} \mathrm{Taq,} 1 \mu \mathrm{l}$ each primer (FP1 and RP1), 32 $\mu \mathrm{lddH_{2 }} \mathrm{O}$, and $2.5 \mu \mathrm{l}$ DNA template. The reaction procedure comprised an initial denaturing step at $94{ }^{\circ} \mathrm{C}$ for $30 \mathrm{~s}$, followed by 40 cycles at $94^{\circ} \mathrm{C}$ for $15 \mathrm{~s}, 58^{\circ} \mathrm{C}$ for $34 \mathrm{~s}$, and $72{ }^{\circ} \mathrm{C}$ for $10 \mathrm{~s}$.

PCR products were purified using a Universal DNA Purification Kit (Tiangen Biotech), according to the manufacturer's instructions. The purified products were then subcloned into the pMD-19T vector overnight at $4{ }^{\circ} \mathrm{C}$ and recombinant plasmids transferred into Escherichia coli $\mathrm{DH} 5 \alpha$ [25]. Recombinant plasmids were extracted using a Mini Plasmid Kit (Tiangen Biotech) and confirmed by DNA sequencing. Plasmid concentration was detected using an ultra-micro nucleic acid protein instrument (Thermo Fisher Scientific, Waltham, USA), plasmids were diluted to $2.6 \mathrm{ng} / \mu \mathrm{l}$, and a 10-fold gradient dilution, up to $10^{-9}$, generated using sterile double distilled water for use in real-time PCR detection.

Real-time PCR primers were designed according to a specific DNA fragment used as target sequence (GenBank: FN356222.1), which was identified in our previous study (our unpublished data). The forward primer 2 (FP2: 5'-CCG AAC ACT TCA AGG AAC AGT TTA G-3') and the reverse primer 2 (RP2: 5'-CTT CCT CGT TTC AGG TTA GAT ATA GC-3) were used (Fig. 1). The total

FP1
Fig. 1 Relationship between two pairs of primers (FP1/RP1 and FP2/
RP2)

reaction system volume was $20 \mu \mathrm{l}$, including $10 \mu \mathrm{l} 2 \times$ ChamQ Universal SYBR qPCR Master Mix (Vazyme Biotech, Nanjing, China), $0.4 \mu \mathrm{l}(10 \mu \mathrm{mol} / \mathrm{l})$ of each primer

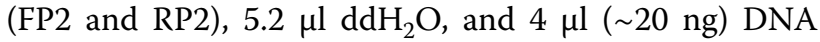
template. The reaction procedure comprised an initial denaturing step at $94{ }^{\circ} \mathrm{C}$ for $30 \mathrm{~s}$, followed by 40 cycles at $94{ }^{\circ} \mathrm{C}$ for $15 \mathrm{~s}, 58{ }^{\circ} \mathrm{C}$ for $34 \mathrm{~s}$, and $72{ }^{\circ} \mathrm{C}$ for $10 \mathrm{~s}$, and a melting curve step, comprising denaturation at $95{ }^{\circ} \mathrm{C}$ for $15 \mathrm{~s}$, annealing at $60{ }^{\circ} \mathrm{C}$ for $15 \mathrm{~s}$, and extension at $72{ }^{\circ} \mathrm{C}$ for $15 \mathrm{~s}$ using real-time PCR.

Optimization of annealing temperature was conducted using the $S$. japonicum target gene plasmid as a template, with annealing temperatures of $57{ }^{\circ} \mathrm{C}, 58^{\circ} \mathrm{C}$ and $59^{\circ} \mathrm{C}$. To optimize plasma volume, 400, 500, 600 and $750 \mu$ l plasma from the same 10 positive goat samples were used. Furthermore, the amount of template DNA was optimized by extracting 10 nucleic acid samples from $600 \mu \mathrm{l}$ plasma from infection-positive goats, using an annealing temperature of $58{ }^{\circ} \mathrm{C}$ and either $2 \mu \mathrm{l}$ (approximately $10 \mathrm{ng}$ ) or $4 \mu \mathrm{l}$ (approximately $20 \mathrm{ng}$ ) template.

\section{Detection of schistosomiasis japonica by real-time PCR}

The plasmid containing the target sequence was used as a positive control. DNA from uninfected negative goat plasma was used as a negative control, and sterile double distilled water was used as a blank control in each assay. In each PCR detection, the positive control, the negative control and the blank control were included. All samples, positive control, negative control and blank control were detected in duplicate. Assays were performed using a qTOWER 3G instrument (Analytik Jena AG, Jena, Germany), and results determined using melting curve analysis. Samples were judged positive when both duplicate reactions were positive; suspicious when one reaction was positive, and sample nucleic acid re-extracted for a second detection, following which samples were judged as positive if one reaction was positive; and a sample was considered negative when two reactions were negative.

\section{Detection of schistosomiasis japonica by ELISA}

Schistosoma japonicum soluble egg antigens (SEA) were prepared according to previously described methods [26]. SEA were the detection antigen and all serum samples were tested by ELISA. First, SEA were diluted appropriately with coating solution, used to coat 96-well microtiter plates (100 $\mu \mathrm{g}$ per well; Corning, Corning, USA) overnight at $4{ }^{\circ} \mathrm{C}$, then washed three times with $0.05 \%$ Tween 20 in PBS (PBST). Next, plates were blocked with $1 \%$ BSA $\left(100 \mu \mathrm{l} /\right.$ well), incubated for $1 \mathrm{~h}$ at $37{ }^{\circ} \mathrm{C}$, then washed three times. Serum samples were diluted 1:100 with PBS, added (100 $\mu \mathrm{l} /$ well), incubated for $2 \mathrm{~h}$ at $37^{\circ} \mathrm{C}$, and washed three times. HRP-labeled donkey anti-goat IgG $(\mathrm{H}+\mathrm{L})$ (Beyotime, Shanghai, China) diluted 1:3000 in 
PBST was added (100 $\mu \mathrm{l} /$ well), incubated for $1 \mathrm{~h}$ at $37^{\circ} \mathrm{C}$, and then washed three times. Finally, $100 \mu \mathrm{l} /$ well soluble TMB substrate solution (Tiangen Biotech) was added, plates incubated in the dark for 5-10 min, and reactions stopped by adding $2 \mathrm{M}$ sulfuric acid $(50 \mu \mathrm{l} /$ well). Optical density (OD) was measured at $450 \mathrm{~nm}$ on a microplate reader (BioTek, Vermont, USA). In each ELISA detection, a positive serum control and a negative serum control were included. All samples, positive serum control and negative serum control were detected in triplicate. The mean absorbance value of the reference negative serum multiplied by 2.1 was set as the cutoff value. A sample was judged positive when its mean absorbance value was higher than the cutoff value.

\section{Statistical analysis}

Sensitivity and specificity were calculated as follows: sensitivity $=$ no. of true positives/(no. of true positives + false negatives); specificity $=$ no. of true negatives $/$ (no. of true negatives + false positives). Stata/SE 12.0 was used to calculate $95 \%$ confidence intervals (CI) for the sensitivity and specificity of each detection. The mean and standard deviation (SD) were calculated. Comparisons among methods of analysis were conducted using a Chi-square test in SPSS Statistics (version 20). A value of $P<0.05$ was considered statistically significant.

\section{Results}

\section{Establishment of a real-time PCR detection system to detect S. japonicum}

The real-time PCR results were determined using melting curve analysis (Fig. 2). The results showed that the positive detection rates were $100 \%(10 / 10)$ at annealing temperatures of $57{ }^{\circ} \mathrm{C}$ and $58{ }^{\circ} \mathrm{C}$; however, the melting curve for the reaction had more than one peak at $57^{\circ} \mathrm{C}$. At an annealing temperature of $59^{\circ} \mathrm{C}$, the detection positive rate was $90 \%(9 / 10)$ and the melting curve had single peak. Therefore, we concluded that $58{ }^{\circ} \mathrm{C}$ was the optimum annealing temperature.

The positive detection rates using 400, 500, 600 and $750 \mu \mathrm{l}$ goat plasma samples were $60 \%(6 / 10), 80 \%(8 / 10)$, $100 \%(10 / 10)$ and $100 \%(10 / 10)$ by real-time PCR; hence, the optimal plasma volume was determined as $600 \mu \mathrm{l}$. Real-time PCR was performed using $2 \mu \mathrm{l}(c .10 \mathrm{ng})$ and $4 \mu \mathrm{l}(c .20 \mathrm{ng})$ template, and the detection positive rates were $80 \%(8 / 10)$ and $100 \%(10 / 10)$, respectively; hence, the final optimal template amount was determined as 4 $\mu \mathrm{l}$.

\section{Detection using plasma and serum samples}

Nucleic acids samples were extracted from 32 positive goat plasma and corresponding serum samples and analyzed by real-time PCR detection using the same conditions. The results showed that all 32 plasma samples were positive (32/32, 95\% CI: 89.11-100\%) and 27 serum samples were positive (84.38\%, 27/32, 95\% CI: $67.21-94.72 \%)$. These data indicate that plasma samples were more suitable for detection than serum samples.

\section{Effects of plasma storage}

Next, real-time PCR was performed using samples stored in different environments and for various lengths of time. After storage of plasma samples for 14 days at $4{ }^{\circ} \mathrm{C}$, $-20{ }^{\circ} \mathrm{C},-40{ }^{\circ} \mathrm{C}$ and $-80{ }^{\circ} \mathrm{C}$, detection rates were $100 \%$ $(10 / 10)$. Nine samples were positive $(90 \%, 9 / 10)$ following storage at $4{ }^{\circ} \mathrm{C}$ after 28 days, while detection rates of samples stored at the three other temperatures were $100 \%(10 / 10)$. Three samples were positive $(30 \%, 3 / 10)$ after storage at $4{ }^{\circ} \mathrm{C}$ for 42 days, while detection rates for samples stored at the other three temperatures were $100 \%(10 / 10)$; the detection rates for all samples stored at $-20{ }^{\circ} \mathrm{C},-40{ }^{\circ} \mathrm{C}$, and $-80{ }^{\circ} \mathrm{C}$ were $100 \%(10 / 10)$ after 3 months, 6 months, and 1 year, respectively (Table 1 ).

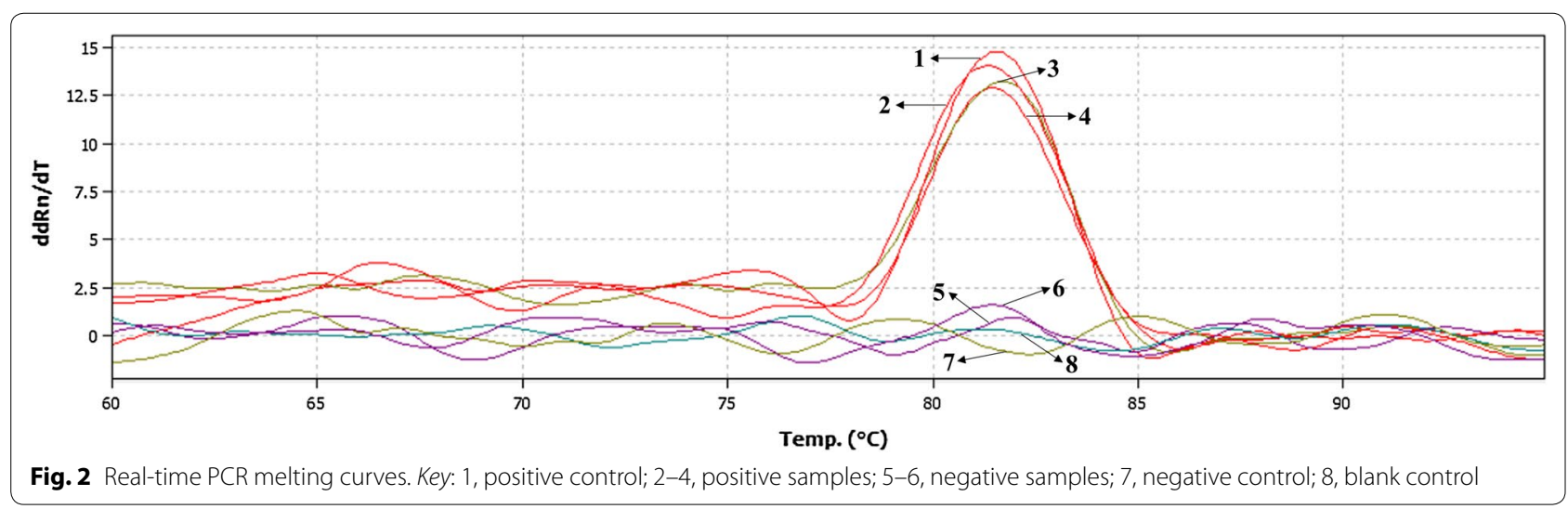


Table 1 Results of real-time PCR analysis of plasma following storage for various time periods and at different temperatures

\begin{tabular}{lllll}
\hline Storage time & \multicolumn{4}{l}{ Temperature } \\
\cline { 2 - 5 } & $4{ }^{\circ} \mathrm{C}$ & $-20^{\circ} \mathrm{C}$ & $-40{ }^{\circ} \mathrm{C}$ & $-80{ }^{\circ} \mathrm{C}$ \\
\hline 14 days & $100 \%$ & $100 \%$ & $100 \%$ & $100 \%$ \\
28 days & $90 \%$ & $100 \%$ & $100 \%$ & $100 \%$ \\
42 days & $30 \%$ & $100 \%$ & $100 \%$ & $100 \%$ \\
3 months & na & $100 \%$ & $100 \%$ & $100 \%$ \\
6 months & na & $100 \%$ & $100 \%$ & $100 \%$ \\
12 months & na & $100 \%$ & $100 \%$ & $100 \%$ \\
\hline
\end{tabular}

Abbreviation: na, no detection

\section{Sensitivity and specificity of real-time PCR and ELISA}

The results of real-time PCR showed that there was no target gene amplification from goat genomic DNA, while the assay could be used to detect schistosomiasis japonica in goats. Sample concentration was calculated using a standard curve based on a 10-fold gradient dilution of the positive control plasmid. The amplification curve (Fig. 3) indicated that the lowest detection level was $10^{-7}$ dilution, with a corresponding copy number of 74.9. The copy numbers of the target gene in one egg, a single male, and a single female of $S$. japonicum were $(8.73 \pm 0.03) \times 10^{6}$, $(8.61 \pm 0.03) \times 10^{9}$, and $(5.51 \pm 0.03) \times 10^{9}$, respectively

The sensitivity and specificity of real-time PCR were 98.74\% (157/159, 95\% CI: 95.53-99.85\%) and 100\% (94/94, 95\% CI: 96.15-100\%), respectively. Meanwhile, the sensitivity and specificity of ELISA were $98.11 \%$ (156/159, 95\% CI: 94.59-99.61\%) and 90.43\% (85/94, 95\% CI: 82.60-95.53\%), respectively. There was no significant difference in sensitivity between real-time PCR and ELISA for detecting goat schistosomiasis japonica $(P=0.652)$; however, there was a significant difference in the specificity of the two methods in goat samples $(P=0.002)$.

\section{Cross-reactivity of real-time PCR}

PCR assays using genomic DNA of eight parasite species (H. contortus, F. gigantica, T. gondii, Sarcocystis sp., T. spiralis, Paramphistomum, Babesia and Spirometra) as template were negative, with no amplification of the target gene detected. Thus, our real-time PCR method exhibited no cross-reactivity with these organisms.

\section{Real-time PCR detection using samples from goats from endemic and non-endemic areas}

Our real-time PCR method was used to analyze 120 plasma samples from goats from an endemic area (Wangjiang) and 33 from goats from a non-endemic area (Weihai). The results showed that the positive rate of samples from Wangjiang was $8.33 \%(10 / 120,95 \% \mathrm{CI}$ : 4.07-14.79\%), while that in Weihai was $0 \%(0 / 33,95 \% \mathrm{CI}$ : $0-10.58 \%)$.

\section{Discussion}

More than 40 mammalian species can be reservoir hosts of S. japonicum, and goats are an important source of human infection. Due to large-scale treatment with praziquantel, safety education, and extensive comprehensive control strategies, the prevalence and infection intensity of schistosomiasis japonica have been reduced successfully and maintained at a very low level [27, 28]; however, the disease continues to spread, although at a very lowintensity of infection, and eggs in the feces of goats are one of the main sources of transmission [29].

Currently, no S. japonicum diagnosis is available with easy field access and high sensitivity and specificity in low-intensity infection areas [30]. Thus, schistosomiasis diagnosis remains challenging in areas of low infection intensity [31, 32]. The real-time PCR method has numerous advantages for diagnosis, including its high sensitivity, high specificity, low cross-reactivity with other

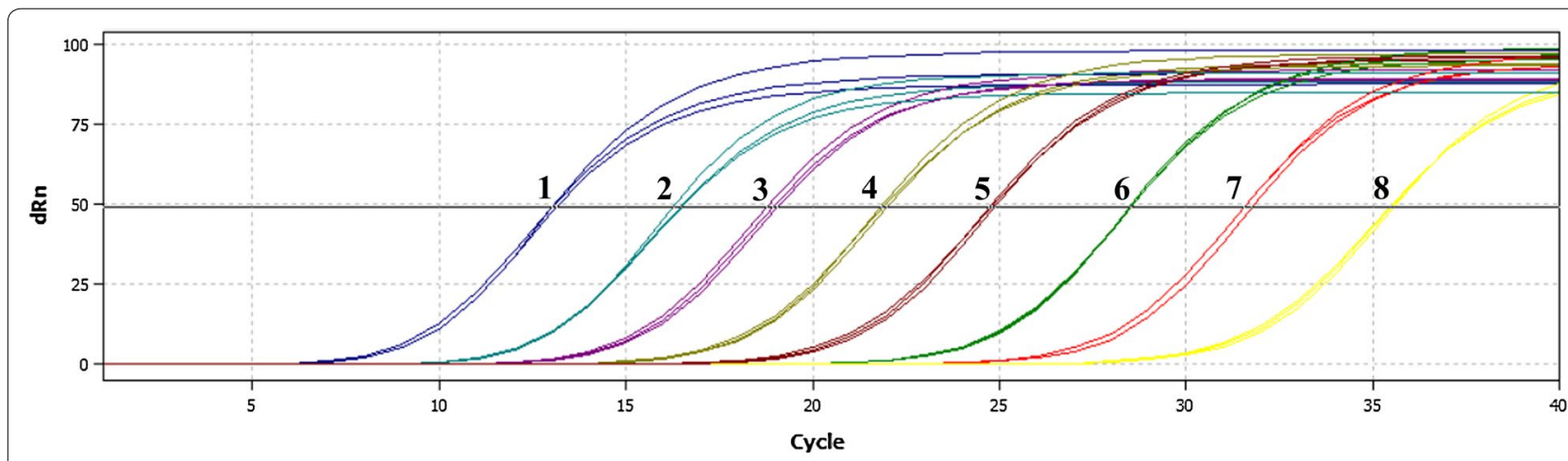

Fig. 3 Real-time PCR amplification curves for the positive control plasmid at different dilutions. Key: 1-8, plasmid diluted at $1(1 \mathrm{ng} / \mu \mathrm{ll}) ; 10^{-1}(100$ $\mathrm{pg} / \mathrm{\mu l}) ; 10^{-2}(10 \mathrm{pg} / \mu \mathrm{ll}) ; 10^{-3}(1 \mathrm{pg} / \mu \mathrm{ll}) ; 10^{-4}(100 \mathrm{fg} / \mu \mathrm{l}) ; 10^{-5}(10 \mathrm{fg} / \mu \mathrm{l}) ; 10^{-6}(1 \mathrm{fg} / \mu \mathrm{l}) ;$ and $10^{-7}(0.1 \mathrm{fg} / \mu \mathrm{l})$, respectively 
parasites, and the fact that the results can be evaluated directly, by the melting curve. Schistosoma japonicum can infect many mammals; however, not all have corresponding commercial secondary antibodies. Thus, the use of immunological methods to diagnose schistosomiasis japonica is limited in different animals. In contrast, the real-time PCR method detects $S$. japonicum nucleic acid, providing the potential advantage for schistosomiasis diagnosis in a range of animals.

In this study, we developed a real-time PCR diagnostic method to detect schistosomiasis japonica in goat plasma samples. The real-time PCR target gene was a specific DNA fragment, previously screened in our laboratory (data not shown). This gene could be detected in schistosomiasis japonica-positive plasma, and there was no cross-reaction with goat genomic DNA. Therefore, we determined that it was suitable for use in detecting schistosomiasis japonica in goats.

In previous studies, host serum was generally used for extraction of nucleic acids and PCR detection [33-35]. In the present study, plasma and serum samples from schistosomiasis-positive goats were analyzed. The detection was higher in goat plasma than that in serum. This may be because cell-free DNA is more stable in plasma than serum, and DNase activity is very high in serum, leading to rapid degradation of cell-free DNA. Further, the EDTA used in the preparation of plasma is a DNase inhibitor, and can inhibit cell-free DNA degradation in plasma. Moreover, plasma contains more fibrinogen and clotting factors than serum, and it is possible that serum can drag down a proportion of cell-free DNA during the clotting process, leading to a loss of cell-free DNA in serum compared with plasma [36, 37].

The influences of storage temperature and time on plasma samples were also evaluated in this study. Positive plasma samples were stable at least for one year when stored at $-20{ }^{\circ} \mathrm{C},-40{ }^{\circ} \mathrm{C}$ and $-80^{\circ} \mathrm{C}$. The detection rate was $100 \%$ within two weeks when samples were stored at $4{ }^{\circ} \mathrm{C}$; however, after four weeks at $4{ }^{\circ} \mathrm{C}$, detection rates declined. Therefore, plasma samples should not be stored for over two weeks at $4{ }^{\circ} \mathrm{C}$, and can be used for at least for one year if stored at $-20^{\circ} \mathrm{C},-40^{\circ} \mathrm{C}$, or $-80^{\circ} \mathrm{C}$.

The lower limit of detection for the real-time PCR method was 0.26 fg target gene, with a corresponding copy number of 74.9. Moreover, in single male and female mean $S$. japonicum genome copy numbers were $(8.61 \pm 0.03) \times 10^{9}$ and $(5.51 \pm 0.03) \times 10^{9}$, respectively, while a single egg contained only $(8.73 \pm 0.03) \times 10^{6}$ copies. In previous study, we reported a nested-PCR method that can detect target DNA from a single egg; however, it required two-rounds of reactions, which could increase the risk of contamination [7]. In contrast, the real-time PCR assay developed here only requires a single-round reaction and the results can be judged directly by melting curve analysis, which is a potentially significant advantage.

In this study, the real-time PCR exhibited slightly better performance than ELISA for detection of S. japonicumpositive samples. There was no significant difference in sensitivity between real-time PCR and ELISA for detection of schistosomiasis japonica-positive samples from goats $(P=0.652)$; however, there was a significant difference in specificity between the two methods $(P=0.002)$. Hence, real-time PCR may improve the specificity of schistosomiasis diagnosis in goats, with superior specificity compared with ELISA.

In addition, the real-time PCR method did not crossreact with $H$. contortus, $F$. gigantica, $T$. gondii, Sarcocystis sp., T. spiralis, Paramphistomum, Babesia and Spirometra. Nevertheless, in some previous studies, ELISA methods cross-reacted with $H$. contortus in goats and Paramphistomum in water buffaloes [13, 38]. Thus, our real-time PCR method has the potential to improve the detection accuracy compared with that achieved using an ELISA approach.

Finally, this method was used to evaluate the goats from endemic and non-endemic regions. No samples from Weihai tested positive, while ten samples from Wangjiang did. In a previous study, a nested-PCR method was also used to evaluate the schistosomiasis japonica infection in goats from Wangjiang, and the positive rate was $16.67 \%$ [7]. Although real-time PCR may be a more sensitive method than nested-PCR, the positive rate using real-time PCR was slightly lower (8.33\%) than that using nested-PCR. We speculate that this may be due to the considerable efforts made to control and prevent schistosomiasis japonica in goats in Wangjiang; however, our data demonstrate that schistosomiasis japonica infection in goats in endemic regions remains at a high level and warrants further attention. Plasma samples from goats from Weihai were all negative, confirming that the realtime PCR method has excellent specificity. In this study, DNA extracted from the plasma of goats was finally selected for detection after comparing the diagnostic effect of plasma and serum from goats. Meanwhile, to the best of our knowledge, this is the first time schistosomiasis japonica has been diagnosed in goats by real-time PCR. The sensitivity and specificity of this method was not worse than other PCR methods that have been used to diagnose schistosomiasis in human or other animals for detecting DNA from different samples. However, real-time PCR also has some shortcomings, such as reliance on expensive instruments and its higher cost, which would be resolved with continuous development. 


\section{Conclusions}

The real-time PCR method developed in this study has higher sensitivity and specificity than previously published approaches and has potential for application for detection of S. japonicum infection in domestic animals, particularly goats.

\section{Abbreviations}

ELISA: enzyme-linked immunosorbent assay; MHT: miracidium hatching test; IHA: indirect hemagglutination assay; LAMP: loop-mediated isothermal amplification; RPA: recombinant enzyme polymerase amplification; SEA: soluble egg antigen.

\section{Acknowledgements}

The authors wish to thank Hao Li and Ke Lu from the National Reference Laboratory of Animal Schistosomiasis, Shanghai Veterinary Research Institute, Chinese Academy of Agricultural Sciences, for technical assistance with parasite collection.

\section{Authors' contributions}

QG, CC, KZ and YY performed the experiments. QG drafted the manuscript. $\mathrm{YH}$ and $J \mathrm{~L}$ designed the study and critically revised the manuscript. QG, $J$ and ZF performed the statistical analysis. YL, LT, JZ, PS and KZ, provided most of materials needed. All authors read and approved the final manuscript.

\section{Funding}

This study was supported by the Shanghai Science and Technology Promotion Agriculture Innovation Program (2019No.3-3), the National Key Research and Development Program of China (2017YFD0501306), the National Natural Science Foundation of China $(31402192,31872256)$ and the Scientific and Technical Innovation Project of the Chinese Academy of Agricultural Sciences.

\section{Availability of data and materials}

Data supporting the conclusions of this article are included within the article.

\section{Ethics approval and consent to participate}

All animals were approved by the Animal Care and Use Committee of the Shanghai Veterinary Research Institute.

\section{Consent for publication}

Not applicable.

\section{Competing interests}

The authors declare that they have no competing interests.

\section{Author details}

${ }^{1}$ National Reference Laboratory of Animal Schistosomiasis, Key Laboratory of Animal Parasitology of Ministry of Agriculture, Shanghai Veterinary Research Institute, Chinese Academy of Agricultural Sciences, Shanghai 200241, P. R. China. ${ }^{2}$ Huancui Development Center for Animal Husbandry, Weihai 264200, P. R. China. ${ }^{3}$ Wangjiang County Center for Animal Disease Control and Prevention, Anqing 246000, P. R. China. ${ }^{4}$ Center for Disease Control and Prevention of Huancui, Weihai 264200, P. R. China.

Received: 20 June 2020 Accepted: 21 October 2020

Published online: 27 October 2020

\section{References}

1. Gryseels B, Polman K, Clerinx J, Kestens L. Human schistosomiasis. Lancet. 2006;368:1106-18.

2. LoVerde PT. Schistosomiasis. Adv Exp Med Biol. 2019;1154:45-70.

3. Hotez PJ, Alvarado M, Basanez MG, Bolliger I, Bourne R, Boussinesq $M$, et al. The global burden of disease study 2010: interpretation and implications for the neglected tropical diseases. PLoS Negl Trop Dis. 2014;8:e2865.
4. Utzinger J, Zhou XN, Chen MG, Bergquist R. Conquering schistosomiasis in China: the long march. Acta Trop. 2005;96:69-96.

5. Zhou XN, Wang LY, Chen MG, Wu XH, Jiang QW, Chen XY, et al. The public health significance and control of schistosomiasis in China then and now. Acta Trop. 2005;96:97-105.

6. Qian C, Zhang Y, Zhang X, Yuan C, Gao Z, Yuan H, et al. Effectiveness of the new integrated strategy to control the transmission of Schistosoma japonicum in China: a systematic review and meta-analysis. Parasite. 2018;25:54.

7. Zhang X, He CC, Liu JM, Li H, Lu K, Fu ZQ, et al. Nested-PCR assay for detection of Schistosoma japonicum infection in domestic animals. Infect Dis Poverty. 2017;6:86

8. Zhang LJ, Xu ZM, Guo JY, Dai SM, Dang H, Lu S, et al. Endemic status of schistosomiasis in People's Republic of China in 2018. Zhongguo Xue Xi Chong Bing Fang Zhi Za Zhi. 2019;31:576-82.

9. de Noya B, Ruiz R, Losada S, Colmenares C, Contreras R, Cesari IM, et al. Detection of schistosomiasis cases in low-transmission areas based on coprologic and serologic criteria: the Venezuelan experience. Acta Trop. 2007;103:41-9.

10. Yu JM, de Vlas SJ, Jiang QW, Gryseels B. Comparison of the Kato-Katz technique, hatching test and indirect hemagglutination assay (IHA) for the diagnosis of Schistosoma japonicum infection in China. Parasitol Int. 2007:56:45-9.

11. Barenbold O, Raso G, Coulibaly JT, N'Goran EK, Utzinger J, Vounatsou P. Estimating sensitivity of the Kato-Katz technique for the diagnosis of Schistosoma mansoni and hookworm in relation to infection intensity. PLoS Negl Trop Dis. 2017;11:e0005953.

12. Wang $X Y, X u$ J, Zhao S, Li W, Zhang JF, He J, et al. Estimating the prevalence of schistosomiasis japonica in China: a serological approach. Infect Dis Poverty. 2018;7:62.

13. Lv C, Hong Y, Fu Z, Lu K, Cao X, Wang T, et al. Evaluation of recombinant multi-epitope proteins for diagnosis of goat schistosomiasis by enzyme-linked immunosorbent assay. Parasit Vectors. 2016;9:135.

14. Wang W, Li Y, Li H, Xing Y, Qu G, Dai J, et al. Immunodiagnostic efficacy of detection of Schistosoma japonicum human infections in China: a meta analysis. Asian Pac J Trop Med. 2012;5:15-23.

15. Weerakoon KG, Gobert GN, Cai P, McManus DP. Advances in the diagnosis of human schistosomiasis. Clin Microbiol Rev. 2015;28:939-67.

16. He P, Gordon CA, Williams GM, Li Y, Wang Y, Hu J, et al. Real-time PCR diagnosis of Schistosoma japonicum in low transmission areas of China. Infect Dis Poverty. 2018;7:8.

17. Mwangi IN, Agola EL, Mugambi RM, Shiraho EA, Mkoji GM. Development and evaluation of a loop-mediated isothermal amplification assay for diagnosis of Schistosoma mansoni infection in faecal samples. J Parasitol Res. 2018;2018:7.

18. ten Hove RJ, Verweij JJ, Vereecken K, Polman K, Dieye L, van Lieshout L. Multiplex real-time PCR for the detection and quantification of Schistosoma mansoni and S. haematobium infection in stool samples collected in northern Senegal. Trans R Soc Trop Med Hyg. 2008;102:179-85.

19. Weerakoon KG, Gordon CA, McManus DP. DNA Diagnostics for schistosomiasis control. Trop Med Infect Dis. 2018:3:81.

20. Bischoff FZ, Lewis DE, Simpson JL. Cell-free fetal DNA in maternal blood: kinetics, source and structure. Hum Reprod Update. 2005;11:59-67.

21. Xu J, Liu AP, Guo JJ, Wang B, Qiu SJ, Sun H, et al. The sources and metabolic dynamics of Schistosoma japonicum DNA in serum of the host. Parasitol Res. 2013;112:129-33.

22. Wichmann D, Panning M, Quack T, Kramme S, Burchard GD, Grevelding C, et al. Diagnosing schistosomiasis by detection of cell-free parasite DNA in human plasma. PLoS Negl Trop Dis. 2009;3:e422.

23. Gu K, Li Y, Driguez P, Zeng Q, Yu X, Sun H, et al. Clinical diagnostic value of viable Schistosoma japonicum eggs detected in host tissues. BMC Infect Dis. 2017;17:244.

24. Osada Y, Kumagai T, Masuda K, Suzuki T, Kanazawa T. Mutagenicity evaluation of Schistosoma spp. extracts by the umu-test and V79/ HGPRT gene mutation assay. Parasitol Int. 2005;54:29-34.

25. Kostylev M, Otwell AE, Richardson RE, Suzuki Y. Cloning Should Be Simple: Escherichia coli DH5alpha-mediated assembly of multiple DNA fragments with short end homologies. PLoS One. 2015;10:e0137466. 
26. Hong Y, Sun A, Zhang M, Gao F, Han Y, Fu Z, et al. Proteomics analysis of differentially expressed proteins in schistosomula and adult worms of Schistosoma japonicum. Acta Trop. 2013;126:1-10.

27. Spear RC, Seto EY, Carlton EJ, Liang S, Remais JV, Zhong B, et al. The challenge of effective surveillance in moving from low transmission to elimination of schistosomiasis in China. Int J Parasitol. 2011;41:1243-7.

28. Song LG, Wu XY, Sacko M, Wu ZD. History of schistosomiasis epidemiology, current status, and challenges in China: on the road to schistosomiasis elimination. Parasitol Res. 2016:115:4071-81.

29. Jiao-Jiao L. Strengthening the control of goat schistosomiasis to facilitate the progress towards elimination of schistosomiasis in China. Zhongguo Xue Xi Chong Bing Fang Zhi Za Zhi. 2016;28:481-4.

30. Sun LP, Wang W, Hong QB, Li SZ, Liang YS, Yang HT, et al. Approaches being used in the national schistosomiasis elimination programme in China: a review. Infect Dis Poverty. 2017;6:55.

31. Cao Z, Huang Y, Wang T. Schistosomiasis japonica control in domestic animals: progress and experiences in China. Front Microbiol. 2017;8:2464.

32. Cai P, Weerakoon KG, Mu Y, Olveda RM, Ross AG, Olveda DU, et al. Comparison of Kato Katz, antibody-based ELISA and droplet digital PCR diagnosis of schistosomiasis japonica: lessons learnt from a setting of low infection intensity. PLoS Negl Trop Dis. 2019;13:e0007228.

33. Diab RG, Mady RF, Tolba MM, Ghazala RA. Urinary circulating DNA and circulating antigen for diagnosis of schistosomiasis mansoni: a field study. Trop Med Int Health. 2019;24:371-8.
34. Kato-Hayashi N, Leonardo LR, Arevalo NL, Tagum MN, Apin J, Agsolid $L M$, et al. Detection of active schistosome infection by cell-free circulating DNA of Schistosoma japonicum in highly endemic areas in Sorsogon Province, the Philippines. Acta Trop. 2015;141:178-83.

35. Weerakoon KG, Gordon CA, Williams GM, Cai P, Gobert GN, Olveda RM, et al. Droplet digital PCR diagnosis of human schistosomiasis: parasite cell-free DNA detection in diverse clinical samples. J Infect Dis. 2017;216:1611-22.

36. Wong FC, Sun $K$, Jiang $P$, Cheng YK, Chan KC, Leung TY, et al. Cell-free DNA in maternal plasma and serum: a comparison of quantity, quality and tissue origin using genomic and epigenomic approaches. Clin Biochem. 2016:49:1379-86.

37. Barra GB, Santa Rita TH, de Almeida Vasques J, Chianca CF, Nery LF, Santana Soares Costa S. EDTA-mediated inhibition of DNases protects circulating cell-free DNA from ex vivo degradation in blood samples. Clin Biochem. 2015;48:976-81.

38. Lv C, Fu Z, Lu K, Yue R, Wang T, Cao X, et al. A perspective for improving the sensitivity of detection: the application of multi-epitope recombinant antigen in serological analysis of buffalo schistosomiasis. Acta Trop. 2018;183:14-8.

\section{Publisher's Note}

Springer Nature remains neutral with regard to jurisdictional claims in published maps and institutional affiliations.
Ready to submit your research? Choose BMC and benefit from:

- fast, convenient online submission

- thorough peer review by experienced researchers in your field

- rapid publication on acceptance

- support for research data, including large and complex data types

- gold Open Access which fosters wider collaboration and increased citations

- maximum visibility for your research: over $100 \mathrm{M}$ website views per year

At BMC, research is always in progress.

Learn more biomedcentral.com/submissions 